\section{Intersections}

Canadian Journal of Music

Revue canadienne de musique
Intersections CANADIAN JOURAL OF MUSIC
REVUE CANADIENEE DE MUSIOUH

\title{
Centring The Periphery: Local Identity in the Music of Theodore Antoniou and other Twentieth-Century Greek Composers
}

\section{Michalis Andronikou et Friedemann Sallis}

Volume 33, numéro 1, fall 2012

URI : https://id.erudit.org/iderudit/1025553ar

DOI : https://doi.org/10.7202/1025553ar

Aller au sommaire du numéro

Éditeur(s)

Canadian University Music Society / Société de musique des universités canadiennes

ISSN

1911-0146 (imprimé)

1918-512X (numérique)

Découvrir la revue

Citer cet article

Andronikou, M. \& Sallis, F. (2012). Centring The Periphery: Local Identity in the Music of Theodore Antoniou and other Twentieth-Century Greek Composers. Intersections, 33(1), 11-34. https://doi.org/10.7202/1025553ar

\section{Résumé de l'article}

Cette étude examine divers aspects de l'identité locale dans la musique de Theodore Antoniou et d'autres compositeurs grecs contemporains. On y met en lumière les malentendus et les concepts historiographiques et esthétiques désuets implicites dans l'utilisation de termes tels que " centre " et " périphérie », ainsi que styles musicaux « élevés » et « bas ». On cherche, à travers un survol de l'histoire de la musique savante grecque, à atteindre une meilleure compréhension de ces questions dans ce contexte. La comparaison avec les compositeurs contemporains d'importance tels que György Ligeti, Luigi Nono et Mauricio Kagel soutient la nécessité d’un regard équitable sur toutes les manifestations se trouvant à être à la périphérie d'un centre donné. Le cas de la Grèce - le berceau de la civilisation occidentale - est un exemple important de l'approche problématique de l'historiographie occidentale au regard des concepts de " centre " et de " périphérie ", et qui devrait être corrigé.
Copyright @ C Canadian University Music Society / Société de musique des universités canadiennes, 2014
Ce document est protégé par la loi sur le droit d'auteur. L'utilisation des services d’Érudit (y compris la reproduction) est assujettie à sa politique d'utilisation que vous pouvez consulter en ligne.

https://apropos.erudit.org/fr/usagers/politique-dutilisation/ 


\title{
CENTRING THE PERIPHERY: LOCAL IDENTITY IN THE MUSIC OF THEODORE ANTONIOU AND OTHER TWENTIETH-CENTURY GREEK COMPOSERS
}

\author{
Michalis Andronikou and Friedemann Sallis
}

People select the past they want and need. 一Jim Samson

\section{INTRODUCTION: REDEFINING THE CENTRE}

The Greek words that constitute the model "peripheral-central" would have never been invented by a group of people who considered themselves peripheral. The etymology of the word periphery (perifereia $=$ peri [around] + feromai $[\mathrm{I}$ wander]) suggests a line around a closed figure, point, or area, which, of course, is the centre (kentro). The well-known last words attributed to Archimèdēs (ca. 287-ca. 212 BCE) the inventor of pi, "Do not disturb my circles," suggest that the concept of centre and periphery has been part of mathematical attempts to apprehend and better understand our world since antiquity. ${ }^{1}$ Inasmuch as the centre-periphery model is a very useful tool and is thus ubiquitous in academic writing, categorical terms such these are never neutral. ${ }^{2}$ On the contrary, they are deeply problematic, because they are charged with the political interest of those who invent or use them (Psychopaidēs 1997, 13). In historiography, the idea of "peripheral" is often used by those who consider themselves to be "central" - that is, more noteworthy-and is implied in numerous historiographical or cultural ideas and terms such as orientalism, "which is not about non-western cultures, but about western representations of these cultures" (McEwan 2009, 62).

Despite the hype and excitement brought on by the short-lived upheavals associated with so-called new/postmodern musicology during the waning decades of the twentieth century, the historiography of art music remains conservatively restricted in a narrow "Western" framework with moveable centres,

1 The letter pi is the first letter of the Greek words perimetros (perimeter or circumference) and perifereia (periphery).

2 For a concise history of the application of the centre/periphery concept to music, and particularly to the emerging ideas of Western art and folk music in the eighteenth and nineteenth centuries, see Matthew Gelbart's discussion of the invention of folk and art music (2007, 225-55). For the use of this concept in a discussion of music in the Middle Ages, see Reinhard Strohm's discussion of mainstream and provincial music (1992). 
depending on the writer's point of view. This lens can lead to distortions and omissions of all sorts, both intended and unintended. For example, according to the American musicologist Richard Taruskin, Iannis Xenakis (1922-2001) was a "Romanian-born Greek-speaking composer resident in France" (2005, 5:77). This is not untrue, but the statement is nonetheless misleading. The fact that both of his parents were Greek, who happened to be sojourning in Romania at the time of his birth because of his father's mercantile business, is not mentioned. His schooling in Greece and his studies at the Athens Conservatory and the National Technical University of Athens until his emigration to Paris for political reasons in 1947 are also omitted. Xenakis is the only Greek composer mentioned in Taruskin's monumental History of Western Music. By emphasizing the cosmopolitan aspects of his early biography and blurring his origins, Taruskin effectively homogenizes the composer's identity, allowing Xenakis to be all the more easily assimilated into the list of leading "Western" composers, reinforcing the myth of a globalized and domineering "Western" music. What is at stake in this misapprehension of Xenakis's identity is more than merely a banal example of scholarly negligence.

To begin with, what does Western refer to? For the past half-century, the West has become a remarkably elastic term. Following the Second World War, white Anglo-Saxon Protestant males would more or less instinctively locate the "West" (also known as "the free world") "in a relatively narrow corridor extending (certainly) from London to Lexington, Massachusetts, and (possibly) from Strasbourg to San Francisco" (Ferguson 2012, 14). During this time, the "West" became more than merely a geographical expression. "It is a set of norms, behaviours and institutions with borders that are blurred in the extreme" (Ferguson 2012, 16). With regard to art music, casual usage of the adjectives Western, occidentale, and abendländische refers to a geographical point of origin, underscoring the fact that, until the end of the nineteenth century, much of it was composed in the western half of Europe. ${ }^{3}$ Even when this music was performed on the periphery, such as in Eastern Europe or in the colonial dominions of the Western powers, the places of origin (primarily Italy, France, and Germany) retained control over its reception by supplying the terms and concepts for discourse about it. By the twentieth century, localized production in certain colonial and post-colonial regions began to emerge with recognizable autonomy. The iconic example is, of course, the music of Charles Ives (1874-1954). ${ }^{4}$ However, as astonishingly original as his work is, it remains firmly tied to musical traditions emanating from Western Europe. By midcentury, the spread of these traditions rendered the adjective Western highly problematic. If the music of composers such as Toru Takemitsu (1930-96),

3 The existence of Western Europe can be traced back to Constantine's decision to build a new imperial residence near the banks of the Bosporus in the Greek city of Byzantium in $330 \mathrm{CE}$. The division was first linguistic (Greek versus Latin) and later became religious (Orthodox versus Catholic). The Great Schism of the eleventh century (1054) occurred when Christianity definitively divided into the Greek Orthodox Church in the East and the Roman Catholic Church in the West.

4 In Canada the work of Claude Champagne (1891-1965) and Healy Willan (1880-1968) would be very representative of this spread of European art music to the dominions and colonies of European empires. 
Franghiz Ali-Zadeh (1947-) and Tan Dun (1957-) has its roots in the art music traditions that emerged in Western Europe, neither they nor their music can or should be usefully described as Western. Thus, outside of a relatively short fifty-year period between 1900 and 1950, the terms West and Western applied to art music are at once anachronistic and confusing. Today, what some still call Western art music has become so widely diffused that it will doubtless suffer the same fate as late medieval Latin, generating new traditions and practices as it gradually disappears.

Taruskin is clearly aware of this problem. Indeed, he acknowledges that since the mid-twentieth century "the concept is undergoing sometimes curious change." Rather than engaging the problem, he dismisses it by asserting that Western music is simply a synonym for art music or classical music (2005, 1:xxi-xxii). Unfortunately, this contributes to an already confused project. The "Chronology: Music, Other Arts and Philosophy, History" at the beginning of volume 6 traces the development of Western music from the earliest appearance of musical notation preserved on clay tablets inscribed some time before 1200 BCE in the Babylonian city of Ugarit, a familiar starting point for many West European and American histories of art music. 5 The "Chronology" then goes on for a page and a half presenting a well-known list of people (Pythagoras and Aristoxenus), objects (the Delphic hymn inscribed on a stone tablet dating from $200 \mathrm{BCE}$ ), and events that had a tangible impact on the development of our current music culture (Barulich and Schlotthauer 2005, 2-3). The text of Taruskin's History skirts this information entirely. It begins with the Carolingians, the emergence of Gregorian chant, and the development of our current notation system in the eighth and ninth centuries of our era, leaving the impression that the right hand does not know what the left is doing. The periods before the ninth century (the "Antiquities" as Taruskin labels them) are simply ignored, because "they hardly exist for music" (2005, 1:xxi). ${ }^{6}$ This astonishing statement raises questions about selection criteria and also speaks volumes (no pun intended) on the author's enterprise and intentions. ${ }^{7}$ Rather than presenting "a true history" that is both "catholic and as exhaustive as possible" (1:xxi-xxii), we experience a form of déjà vu. Taruskin's volumes are yet another example of a drearily predictable, teleological view of music history that privileges the rise of polyphonic music over everything else. That this is

5 See, for example, the recent editions of the ubiquitous Grout history (Burkholder, Grout, Palisca 2010, 8-9).

6 The statement is accompanied by an unnecessary and disgraceful jab at one of the author's predecessors. Jacques Chailley is said to have dealt with 39 ,000 years of music on one page (Taruskin 2005, 1:xxi). As noted above, Taruskin dismisses 2,000 years in one sentence. The criticism is just one more unfortunate example of a musicologist criticizing someone else in a poor attempt to cover his own failings, eroding any confidence one might have had in his judgment. He would have been better advised to consult Jacques Handschin's Musik Geschichte im Überblick (1990). The first third of this excellent survey deals with Taruskin's "Antiquities" and would have provided him with much to chew on.

7 The statement is all the more surprising because part 1 of his Music in the Western World: A History in Documents (co-edited and co-annotated with Piero Weiss), entitled "The Heritage of Antiquity," begins with texts written by or attributed to authors of the period (Taruskin and Weiss 2008, $1-19)$. 
a distorted presentation of the music of the Middle Ages hardly needs further explanation. ${ }^{8}$ But of course, in this story, medieval music is merely a pre-text. Volume 1 is a preamble to the main goal: a rearguard action intended to shore up and exalt an invented tradition that is now crumbling-that nineteenthcentury construct that we are pleased to call the classical canon. ${ }^{9}$

To be sure, the massive amount of data contained in these volumes is presented with wit and style, and no history can deal with everything. However Taruskin's omissions and inclusions are puzzling. On the one hand, the music of Greece (as well as the other regions of Southeastern Europe) is absent from the start and remains outside to the bitter end. On the other hand, Russia and North America are given extensive coverage, even though both (to paraphrase Taruskin) "hardly exist" for the development of the music he is talking about until the second half of the nineteenth century. This has led Kaiti Romanou $(2006,207)$ to claim that Taruskin's History is in fact a belated nationalisation of Western music history by Americans. Her assertion rings true.

The nationalization of history is not new. The older music histories of Germany, France, and Italy traditionally assumed that their national perspectives are of central importance, relegating the music of other nations to the periphery. Furthermore, as Carl Dahlhaus $(1989,90)$ reminds us, nationalist perspectives on music arise as a result of the writing of national histories of music. They are the product of music historians and critics rather than of composers. Thus it is hardly surprising that, following its rise to the status of a world power, the United States should produce musicologists who firmly believe that they are writing from the centre. Nevertheless, this shift in authorial perspective from Western Europe to North America is deeply ironic. Only thirty years ago Joseph Kerman $(1985,39)$ noted, "The main reason American musicologists do not work more with American music is because there is so brief a tradition of art music that can be taken seriously." He was correct, of course. Until the second half of the twentieth century, most of North America (outside of a few urban centres on the eastern side of the continent) was a cultural and musical backwater. Taruskin's use of the term Western in his title functions as a fig leaf, allowing him to include the newly rich among the more established objects of his study.

In our text, we shall argue that the music of the place we now call Greece deserves better and more sustained attention. While we support the idea that all places that find themselves peripheral to a given centre deserve fair and equitable treatment, we feel that the place of Greece in the history of art music is different and special, for a number of reasons. First, Greeks trace their language and their cultural identity in an uninterrupted evolution going back to antiquity. To be sure, both the language and the demographic make-up of the

8 For comment and the beginnings of a corrective, see Curry $(2011,171)$.

9 For Eric Hobsbawm $(2012,1)$, an invented tradition means "a set of practices normally governed by overtly or tacitly accepted rules and of a ritual or symbolic nature, which seek to inculcate certain values and norms of behavior by repetition, which automatically implies continuity with the past." Nothing fits this definition better than the performance practice that has grown up around Western art music over the past two centuries. 
region have continuously evolved over the past three millennia, but classical culture was never lost in Byzantium, so it never had to be rediscovered. Periodic revivals occurred, but there could be no Byzantine Renaissance, at least not in the Western sense (Kaldellis 2007, 4), a characteristic shared with other cultures of Eastern Europe.

Second, the music traditions of Greece (both liturgical and popular) have continued to be an integral part of the development of art music. Recent research has shown the uninterrupted presence of national/popular elements in the works of nineteenth-century composers from Nikolaos Mantzaros (1795-1872) to Dionyssios Lavrangas (1860-1941) (Leotsakos 2001). In Greece, the demarcation between art and popular music, so typical of Western music cultures, is less clearly defined. Indeed the whole notion of high- and low-brow music is difficult to apply to the music of Greece. ${ }^{10}$ This dichotomy is replaced by a grey-scale that runs from secular, orally transmitted folk music, through the liturgical practice of the church and rebetika to art music. Rebetika, an urban folk music initially associated with lower-class / shady characters, is made up of a mix of demotika (rural folk music) from different parts of Greece and the former Greek territories in Asia Minor in a style that also uses Western concepts of harmony. It is a product of Greek modernity (a form of music that arose after 1830). Following the Second World War, rebetika was foundational for the development of entechno-laiko (art-popular song) that was pioneered and promoted by Mikēs Theodorakēs (1925-) and Manos Hadzidakis (1925-94). ${ }^{11}$ This new form of popular music bridges the gap between folk music and art music. Comparable phenomena might be the songs of Kurt Weill or George Gershwin, though the work of neither composer captures the collective imagination in such a broad way that rebetika and the entechno-laiko do in Greece. Furthermore, both Theodorakēs and Hadzidakis were classically trained and contributed to the production of art music in Greece by composing numerous works for symphonic orchestra.

Finally, the contributions of Greece to our music culture are of an order different from those of other cultures currently understood as peripheral, such as Estonia, Norway, Scotland, Portugal, and Canada. Concepts such as the Pythagorean codification of intervals in terms of consonance and dissonance have been embedded at the very core of the music of Western Europe for the past two millennia. From Boethius to Johannes Kepler, the music of the

10 The invention of the national categories of folk and art music in the West during the eighteenth and nineteenth centuries reinforced the high-low distinction, which became a distinctive and normative feature of Western music culture (Gelbart 2007, 111-52, and 191-224 respectively).

11 The best-known works by Hatzidakis and Theodorakès are the soundtracks of the homonymous movies Never on a Sunday (1960) and Zorba the Greek (1964), respectively. Because of the huge success of both films, these two songs played a significant role in the evolution of the composers' careers, though neither considered the songs to be a significant part of their oeuvre. In fact, they both stated at certain points of their careers that it was unfair for them to be globally recognized for these works while the core of their significant work remains unknown. Hatzidakis insisted that the success of Never on a Sunday was beyond his intentions and therefore it did not belong to him. According to a story that is widely known in Greece, he attempted to deal with the psychological pressure that this success created by throwing the statuette that he received for the Academy Award for Best Original Song in the household waste, where it was recovered by the cleaning lady. 
spheres nourished the Western world's musical imagination and thought. The same can be said of Plato's reflections on the social function of music. Even the words we use (melody, harmony, polyphony) derive from Greek. On a more pragmatic level, the Carolingians consciously used the musical knowledge of Byzantine culture as they assembled the tools they needed to improve their understanding of music. Indeed, the flow of information on music from East to West in the seventh and eighth centuries reached such proportions that the Roman liturgy "was in serious danger of being Orientalized" (Hoppin 1978, 49). Ideas about Greek music, though often mistaken, provided a foundation for musical innovation in the early modern period (see, for example, activities of the Académie de Poésie et de Musique formed in 1570 by Jean-Antoine Baif and Joachim Thibault de Courville). The birth of opera is perhaps the most spectacular example of the impact that ideas about the musical culture of antiquity (flawed as they were) have had on the music of the last four hundred years. Both Gluck and Wagner justified their reforms of opera on their respective understandings of Greek music culture. In our own time, the British composer John Tavener (1944-2013) and his student Ivan Moody (1964-) have sought inspiration and techniques from the musical traditions of the Greek Orthodox Church. When compared to the enormous inheritance that we have all received from Greece, the contributions of North America and other postcolonial places pale to insignificance. ${ }^{12}$

In this text, we will be examining the music of five Greek composers born during the first half of the twentieth century: Nikos Skalkōttas (1904-49), Michalēs Adamēs (1929-2013), Theodore Antoniou (1935-), Dimitri Terzakis (1938-), and Kyriakos Sfetsas (1945-). They were chosen because their music represents the latent hybridity that has been a hallmark of music in Greece, long before the term became fashionable in postmodern discourse in the 1980 os. Of the five, our primary object of study is the music of Theodore Antoniou. To be sure, artists should not be placed in "national strait-jackets." 13 However, it is also true that, for a composer, it is much easier to change one's passport than it is to set aside one's training (Sallis 2003 and 2011a). In the following, we shall examine what we lose in the music of the composers mentioned above, if we remain ignorant of the culture out of which they emerged. In order to do so, we first sketch a short history of art music in Greece.

\section{MUSIC IN GREECE BEFORE 1830}

The Byzantine Empire or Byzantium was the direct continuation of the Roman Empire during late antiquity and the Middle Ages, centred in the capital of Constantinople. Successive civil wars in the fourteenth century further sapped the empire's strength that had been declining since the sacking of Constantinople

12 Using a much broader scale of reference, David Martel Johnson credits pre-classical Greeks with nothing less than the invention of reason: that is, "to begin employing a new set of rules, goals and standards of thinking" (Johnson 2003, 34).

13 For more on the problems involved in assigning identity too narrowly to composers, see Milan Kundera's discussion (2005) of the problematic reception of Leoš Janáček's music. 
by the Latin Crusaders in 1204. As a result, most of its remaining territories were lost in the Byzantine-Ottoman Wars, which culminated in the Fall of Constantinople in 1453 and the conquest of remaining territories by the end of the fifteenth century. Most of the territories within the borders of modern Greece were ruled by the Ottomans from the mid-fifteenth century until its declaration of independence in 1821 . In 1830, Greece became partly independent, after almost four hundred years of subjugation.

The music of Greece has always been influenced by its traditional music. The Byzantine music of the Eastern Orthodox Church is an important component, as are the secular styles of rebetika, demmotika, and many other popular traditions (both rural and urban) that pertain to the different history, contiguity, and peculiarity of the places that make up the Greek cultural space. Folk music remains the most important musical and poetic expression of the rural population. Ethnomusicologists divide Greek rural or traditional music geographically: (1) music of mainland Greece, (2) music of the islands, and (3) music at the edges of the Greek cultural space-that is Pontos, Asia Minor, Cyprus, and the regions near the northern border of the modern nation state. The musical traditions of the eastern Aegean islands are based on modal monophonic songs with the use of microtones. Good examples of this in mainland Greece are the moirologia: dramatically expressive, lament-like songs based on pentatonic scales. An impressive sense of catharsis, derived from ancient Greek tragedies, is preserved and transmitted in these songs.

Until the early decades of the nineteenth century, Western music was unknown to mainland Greeks. However, this was not the case for the Ionian Islands, which were mainly under Venetian (1386-1797), French (1797-1814) and British (1814-64) rule, before their union with Greece. At the beginning of the 1770 , regular opera performances helped to develop an Italian-based musical tradition, which gradually expanded to islands such as Zákynthos, Cephallonia, Lefkas, and, after 1830, to continental Greece. These performances mark the beginning of art music in Greece. ${ }^{14}$

\section{ART MUSIC IN GReECE (1830-1950)}

In 1908, Manolis Kalomoirēs (1883-1962) gave the first concert of his works at the Athens Conservatory. The event is noteworthy because in the program notes he published a manifesto that called for the founding of the Greek National School of music, which would become a virtual "palace to enthrone the national soul" (Leotsakos 2001). It was to be devoted to the development of music infused with elements of folksong and folk rhythms, but based on modern compositional techniques of the late nineteenth century. During his studies in Vienna, Kalomoirēs came under the influence of Wagner's work and later by Russian national music. These affinities shaped his creative personality and aesthetics and led him to denounce the legacy of earlier Greek composers (many of whom came from the Ionian islands) for being too Italianate. He was also opposed to the modernism of the music of Nikos Skalkōttas. During his

14 The first opera was presented at the Teatro S. Giacomo in Corfu in 1733. 
long career as a composer, teacher, and administrator, Kalomoirēs succeeded in imposing his vision, which has resulted in a tripartite division of the history of art music in Greece: (1) the Ionian school (nineteenth century) of composers strongly influenced by Italy, (2) Kalomoirēs's national school (first half of the twentieth century), and (3) modernism in the wake of Skalkōttas's work (second half of the twentieth century).

Nikos Skalkōttas was one of the most significant Greek composers (if not the most) of the twentieth-century (Romanou 2009, 165). He began taking violin lessons from his father and uncle and graduated from the Athens Conservatory at the age of sixteen with a golden medal for his highly acclaimed final recital. In 1921 he moved to Berlin, where he continued his studies on the violin with Willy Hess at the Hochschule für Musik. Between 1925 and 1927 he studied composition with Philipp Jarnach (1892-1982) and Kurt Weill (1900-50) and in 1927 began his studies with Arnold Schoenberg (1874-1951). Poverty and debt forced him to leave Berlin in 1933, leaving behind his manuscripts, which were later sold by his landlady.

Skalkōttas composed prodigiously, in a personal atonal idiom, using the twelve-tone system only occasionally. Schoenberg $(1975,386)$, declared Skalkōttas to be one of his most talented students. Despite this endorsement, performances were rare and, with the exception of four dances and a few other works, for violin and piano (1929), nothing by Skalkōttas was published during his lifetime. Recent research has shed light on the problematic reception of Skalkōttas's work in Greece as well as on his importance for twentiethcentury art music (Vrondos 2009). Skalkōttas's style was eclectic, containing features that can be linked to the music of Schoenberg, Stravinsky, and Bartók (Romanou 2009, 174). He was a leading figure during the first half of the twentieth century, because his music overrides and encompasses the two opposing tendencies in modern music of the first half of the twentieth century represented by the music of Schoenberg and Stravinsky. The unique way of using the twelve-tone system, and its combination with neoclassicism and traditional Greek music, contradicted Adorno's reading of the struggle for the future of European art music. His Greek Dances (1931-36) for orchestra, a project based on Greek folksongs, some of which the composer transcribed from recordings from the Athens archive project of Samuel Baud-Bovy and Melpo Merlier, had a significant impact on how folk music was used to create art music. Rather than squeeze the Greek source into a Romantic idiom as Kalomoirēs had done, Skalkōttas brings the compositional techniques of the twentieth century to bear on his source. His Greek Dances present an example of the "middle path" that is not supposed to lead to Rome (Adorno [1949] 2006, 7). The apparent heterogeneity of this oeuvre reflects the composer's devotion to Greek folk music. This work is basically modal. Though some dances are based on the composer's transcriptions of recordings, not all are strictly authentic. Like the dances of Béla Bartók or Manuel de Falla, they are original compositions that transcend their origins. In the beginning of his "Eppirotikos Dance," a very effective combination of a modal melody, along with a steady harmonic pattern, 

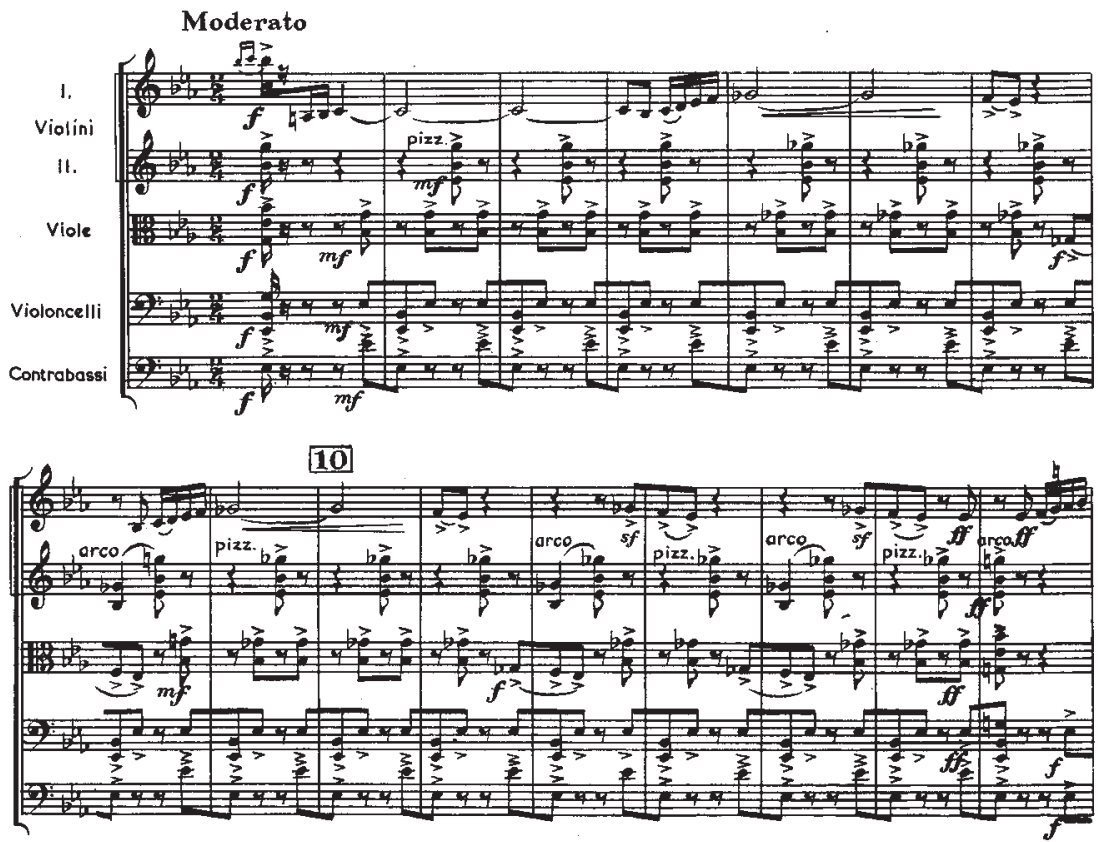

Example 1. Nikos Skalkōttas, "Ēpirotikos," bars 1-16, from 5 griechische Tänze|für Streichquartett|aus A/K 37 (1931-36), editing and double-bass part by Walter Goehr, (C) Copyright 1956 by Universal Edition (London) Ltd., London/UE UE1234 www.universaledition.com

and a lively rhythmic texture reveals a neo-primitive, ritualistic music (see example 1).

Skalkōttas did not limit his exploration of popular music to the orally transmitted songs of the demotika (rural population). In the second movement of his Concerto for Two Violins (1944-45, one of his last works), he included a rebetiko song by Vassilēs Tsitsanēs (1915-84). Consequently, Skalkōttas is considered the first composer to recognize the artistic value of this music. At the time, rebetiko was considered to be the vulgar expression of the uneducated working classes of the slums and suburbs of Athens. It would have been considered an unacceptable intrusion of the music of the lower classes by the Athenians who attended concerts of art music.

Skalkōttas's influence has been considerable, extending to generations of Greek composers. The aesthetic distance that he established between himself and the National School through works like his Greek Dances kept him marginalized during his lifetime, but also set him up to become a foundational figure for the next generations of Greek composers. ${ }^{15}$

15 Very few contemporary composers in Greece have not referred to his music, in interviews, monographs, or collective works about the evolution of contemporary music. For example, see Vrondos (2009) and Zervos (2001). 


\section{Art Music in Greece after 1950}

Following the Second World War and the subsequent civil war in Greece (1946-49), the influence of Kalomoirēs's National School began to wane. The defeat of Nazi Germany and the revelations of the atrocities committed during the Holocaust resulted in a political situation in which nationalist ideologies found themselves in retreat throughout Europe. The regimes that were put in place after the end of the war tended to keep nationalist ideologies of all types on a short leash. The American occupation forces were involved through the re-education programs implanted in the defeated states and through cultural policies designed to counter the growing Soviet influence in Eastern and Central Europe. The impact of these programs and policies was particularly strong in Greece, the only Balkan country not in the Soviet sphere as of 1945. Recently declassified CIA documents confirm that Greece was considered a crucially important component of the U.S. strategy to counter Soviet expansion (CIA 1950). As a result, Greece became the most important beneficiary per capita of American largesse in the world during the postwar period (Mazower 2002, 133).

This context had strong implications for the development of music and especially new music in Greece. During the 1950s and 1960s the new music scene (principally in Athens) changed significantly as composers digested the trends and achievements of a new generation of Western avant-garde composers. The change was all the more radical because it occurred in the wake of the now-fading intellectual framework, based on nineteenth-century concepts and established by Kalomoirēs and his generation. ${ }^{16}$ Furthermore, recent studies have shown how American policies put in place programs that offered significant opportunities to emerging composers in the newly founded German Federal Republic (Beal 2006). Similar opportunities became available to young composers across Europe and notably in Greece. Seminars, workshops, concerts, and conferences pertaining to contemporary music were organized in major cities and especially in Athens. As of the mid-1950s, Günther Becker (1924-), a German-American composer, along with Greek composers and theorists (notably Yiannēs A. Papaiōannou 1910-89) introduced modern music in courses given at the Athens Conservatory. ${ }^{17}$ Young avant-garde composers from Greece received scholarships to study in Western centres. When they came back, they found a cultural context very different from the one to which Skalkōttas had returned in the 1930s. Traditional Greek society and cultural values were being transformed by a significant rise in the urban population, changes in consumer practice, and an increase in political activity (Poulakis

16 This sense of rupture between a worn-out nineteenth-century music culture that had been essentially implanted artificially, and home-grown aspirations to learn more about avant-garde developments, occurred in many places following the Second World War, and Canada is a good example. Barbara Pentland $(1950,43)$ accused a clique of "imported English organists" of being responsible for the poor state of musical culture in Canada. She bitterly complained that an overly long dependence on "a mother country" (Pentland's emphasis) resulted in the stifling of native talent and baldly asserted that she had no older generation of Canadian composers to emulate or admire (Sallis 2003, 10).

17 Both Yiannēs A. Papaiōannou and Becker contributed to the dissemination of Skalkōttas's work in Athens during the 1950s and 1960s (Romanou 2009, 177-78). 
2009, 189-90). They also discovered that many of the innovations adopted by Western pioneers included features that could be found in Greek folk music, such as the use of micro-intervals and modes, free or controlled improvisation, as well as specific vocal and instrumental performance techniques (Romanou 2000, 167-68).

Of the generation of Greek composers who successfully assimilated and contributed to the new music of the post-1945 avant-garde, the most well known is, of course, Xenakis. His reputation is justifiably based on the quality of his work, but the degree to which it has spread is due in large part to the fact that his career "took place" in Paris, one of the traditional centres of Western art music and arguably the most important during the twentieth century. Another Greek composer of equal significance and of the same generation was Janis [Jani] Christou (1926-70), whose career was cut short by a tragic car accident. However, we also know much less about him and his music, because much of his career took place in Greece.

During the 1970 a sea change occurred within what was still called "Western avant-garde" music. The belief or faith in progress and the concomitant teleological view of music history collapsed. Numerous composers, who had led the way following the Second World War, went through stressful periods of re-evaluation. Following the composition of his so-called anti "anti-antiopera" Le grand macabre (1978), György Ligeti entered a fallow period during which he contemplated what to do next. This was not just a personal crisis; it was in the composer's own words "a crisis of the whole generation to which I belong" (Steinitz 2011, 169). Luigi Nono went through a similar short period of reflection following the completion of his second action scenica Il gran sole carico d'amore (1976). This period came to an end with the composition of his string quartet Fragmente-Stille an Diotima (1980), which inaugurated a series of chamber works, many involving live electronics, that are a central feature of Nono's late work (ca. 1980-90). The fact that Ligeti and Nono diverge sharply in compositional technique and aesthetic goals (as well as political outlook) tends to reinforce Ligeti's assertion that the crisis that occurred in their work during the late 1970s was indeed having an impact on an entire generation of composers.

This period of crisis has been interpreted by some as the decline of the postwar avant-garde or of high modernism writ large. Indeed some commentators predicted the advent of a new "post-modern age." 18 The term is, of course, hopelessly confused and contradictory (Sallis 2000, 70-71). The claim, underwritten by this term, that a rupture took place in the development of new music has proven to be false and distorting. Many of those who were responsible for setting the post-1945 avant-garde in motion were not only active but remained dominant figures in the new music scene (as well as Ligeti and Nono, one could also mention Pierre Boulez, Karlheinz Stockhausen, and Luciano Berio among

\footnotetext{
18 See, for example, Lawrence Kramer's outlandish claims that the last decades of the twentieth century witnessed nothing less than "a Nietzschean transvaluation of all values in the human sciences" (1996, xi).
} 
a long list of influential composers). The change that did indeed take place would be better described as one of maturation. Looking back at what they had achieved, many of the leading voices of the fifties and sixties began to reflect on their legacies. Some had to confront the disquieting fact that they were now being subsumed into the very canon that they had once so vehemently criticized. ${ }^{19}$

Be this as it may, the context that opened up during the waning decades of the twentieth century provided new opportunities for composers from Vancouver to Athens and beyond. Narrow, rather dogmatic views of what new music should be and how it should be composed gave way to a multiplicity of approaches and styles. Alongside relentless experimentation with new concepts and sounds that continued without stop (see the development of acousmatic, live-electronic, and digital music, for example), composers both young and old showed a greater tendency to ground their work in their surroundings. In this new context, Greek composers felt encouraged to renew their vocabulary and to reinvestigate their personal music language based on their roots, tradition, and identity.

The emergence of new types of tonality was strongly felt in the music of composers born after 1930, who had grown up with the ideas of the belated Greek national music and had experienced the expansion and domination of avant-garde music in the 1950s. The Greek Composers Union commissioned works for folk instruments and symphonic orchestra. Aspects of popular and avant-garde music were combined in an improvisational style that sounded both new and familiar for Greek audiences. ${ }^{20}$ This change provided some composers with a new sense of purpose. Echoing statements made by Bartók and Zoltán Kodály a half-century earlier, Dimitri Terzakis (n.d.) saw his music as a "blood transfusion" for Western music, which he felt was heading towards a dead end because it had isolated itself from the great Eastern European and non-European musical cultures.

Like Terzakis, Michalēs Adamēs combined Byzantine music tradition with contemporary trends of music. Adamēs used the music of the Eastern Orthodox Church as a point of departure for the genesis of his work, while Terzakis uses its technical elements to create a way of musical expression, characterized by horizontal, melodic forms, which do not follow the occidental temperate system but make use of intervals smaller than semitones. ${ }^{21}$ Thus, Adamēs and Terzakis can be understood as two poles influenced directly by the Byzantine tradition. This specific relation to the Eastern Orthodox tradition

19 See Pierre Boulez's comments on the bombing of opera houses, for example (1970, 285-94).

20 Examples of works for orchestra and folk instruments are the Concertino for Santur and Orchestra (1988) by Dēmētrēs Dragatakēs (1914-2001); Diplochrōmia (1988) for Folk Clarinet and Orchestra by Kyriakos Sfetsas; Concerto for Pontian Lyra and Orchestra (1988) by Ēlias Papadopoulos (1951); and the Concerto for Tamboura (Bouzouki) and Orchestra (1988) by Antoniou, presented at the Athens Concert Hall, by the ALEA III under the direction of the Antoniou, during the "Cycle of Greek Music" Festival, in 1992.

21 Both have composed numerous liturgical and theatrical works for orchestra, instrumental and vocal ensembles, electronic instruments, and multimedia. Their prolific output is the result of numerous commissions from the world's most important cultural associations. 

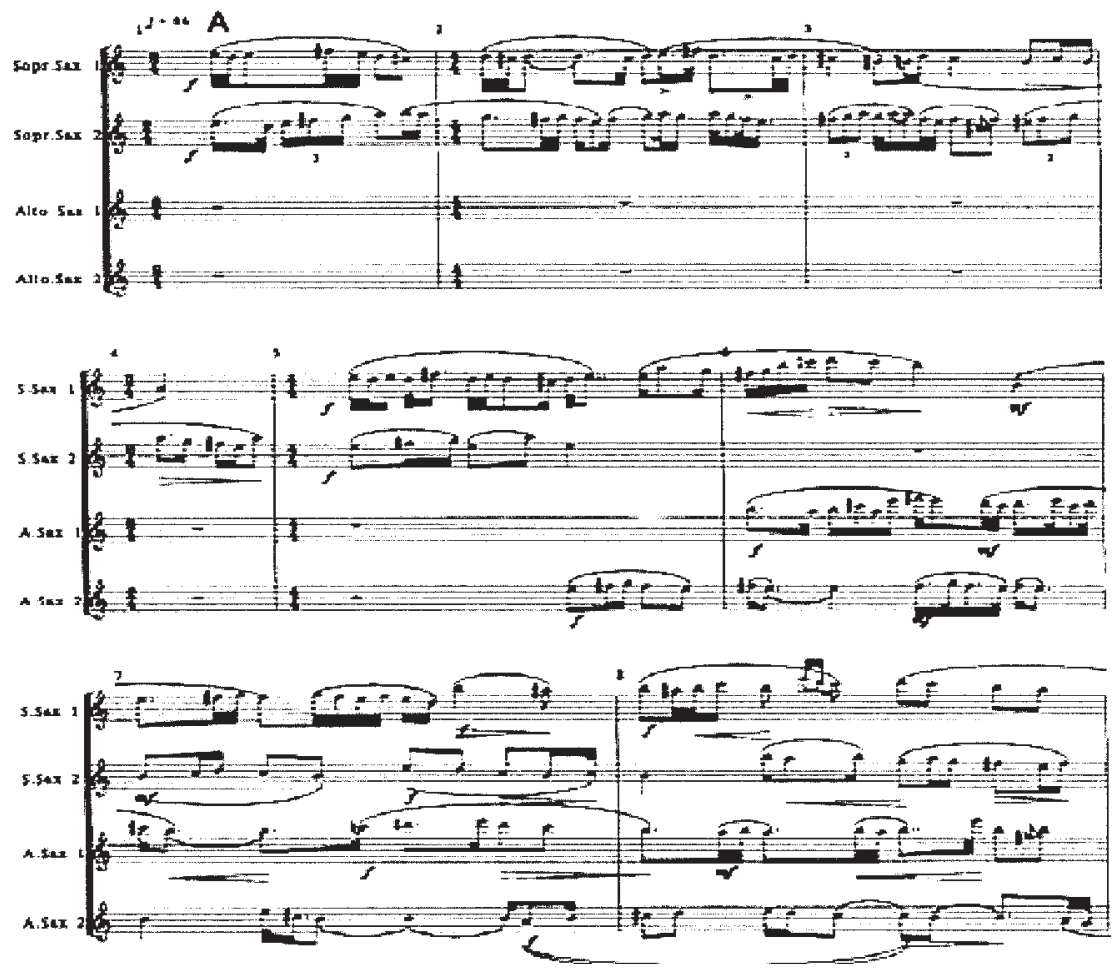

Example 2. Michalēs Adamēs, Kalophōnikon, for two soprano saxophones and two alto saxophones (1988), bars 1-8, with kind permission from the composer.

added a unique character in their personal musical styles. For example, the title of Kalophōnikon (1988) by M. Adamēs refers to the virtuosic genre called "Kalophōnia," which developed in the Eastern Orthodox liturgical tradition, from the fourteenth century onwards. The main characteristics of this genre are the sophisticated, melismatic arches (present in all four voices in example 2 ), the frequent transition of modes and the vocal ranges, as well as the repetition of syllables, words, and phrases, and the use of anagrams, creating a shifting sense of meaning for the attentive and knowledgeable listener. Adamēs's music expands his monophonic source material into a polyphonic genre. The contrapuntal melodic lines give the impression of both a new structure and a new process based on the Byzantine musical tradition.

A similar approach is used by Terzakis, for whom the integration of melodic aspects of Byzantine music tradition into Western contemporary music provides unique melodic possibilities, as well as a way to establish pitch-centred structures outside of the major-minor system as can be seen in Das sechste Siegel (1987). Note the quarter-tone pitch organization in the vocal parts, as in bars 7-10 of example 3. As noted above, the composer considers the complexity of the microtonal texture to be one of his contributions to an enrichment of Western music culture. Whereas Adamēs's references to his Byzantine source 


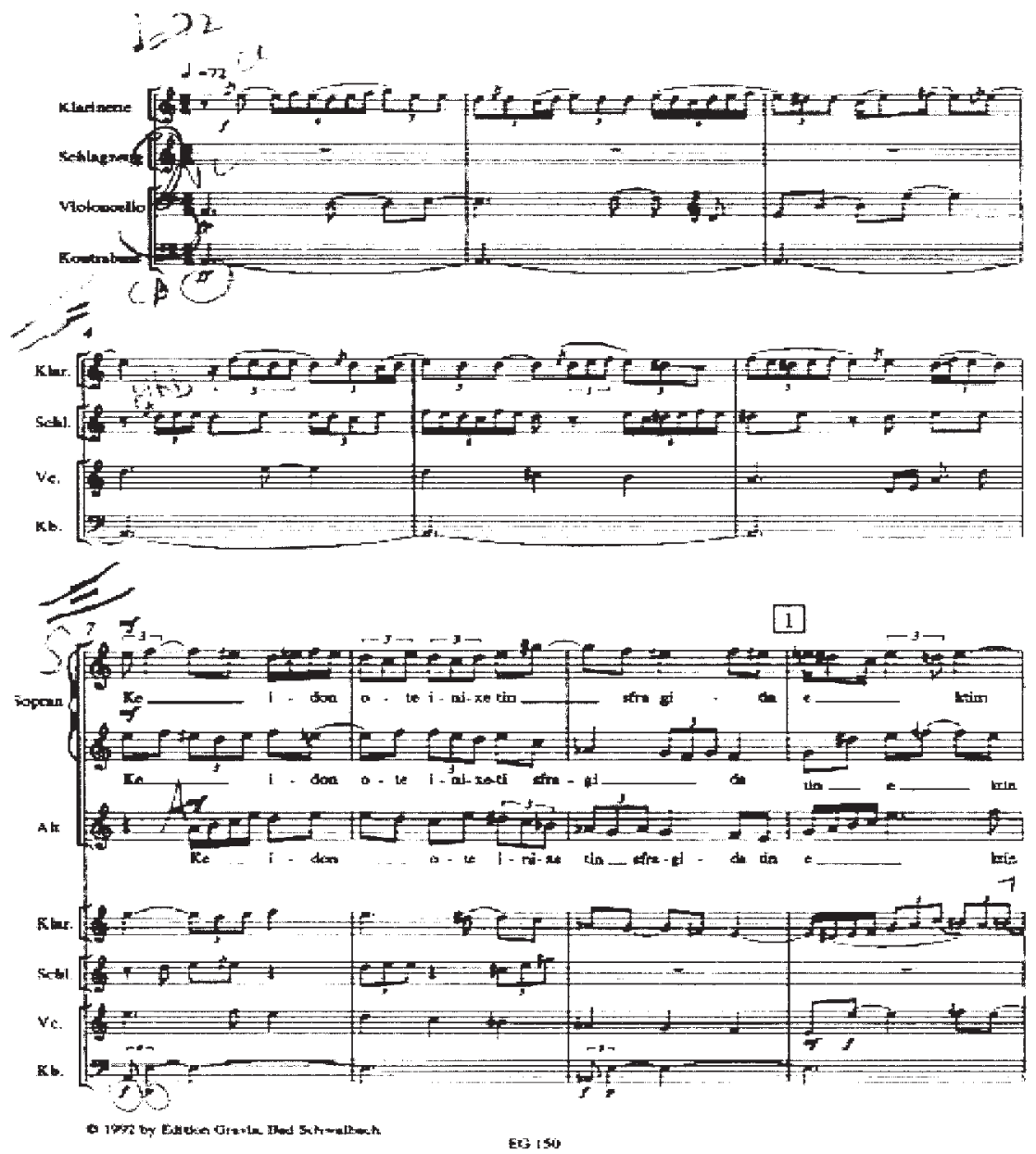

Example 3. Dimitri Terzakis, Das sechste Siegel, for mixed chorus and chamber ensemble (1987), bars 1-10, with kind permission from the composer. (The manuscript markings in the example were made by Theodore Antoniou, who used the score to conduct the work.)

material is clearly evident in the style of his music, Terzakis's use of microtones and modes does not refer directly to the style of the tradition from which it is derived. Terzakis dedicated this work to Ligeti to honour the leading role he played in the development of avant-garde music. The dedication also suggests that Terzakis's ability to develop melodic complexity based on Byzantine music is analogous to Ligeti's development of rhythmic complexity based on the music cultures of sub-Saharan Africa. Be that as it may, Ligeti and Terzakis take significantly different approaches. Whereas Ligeti adopts a typically Western attitude in seeking the exotic to develop his technique, Terzakis and Adamès turn inward, examining the resources of their own culture. 

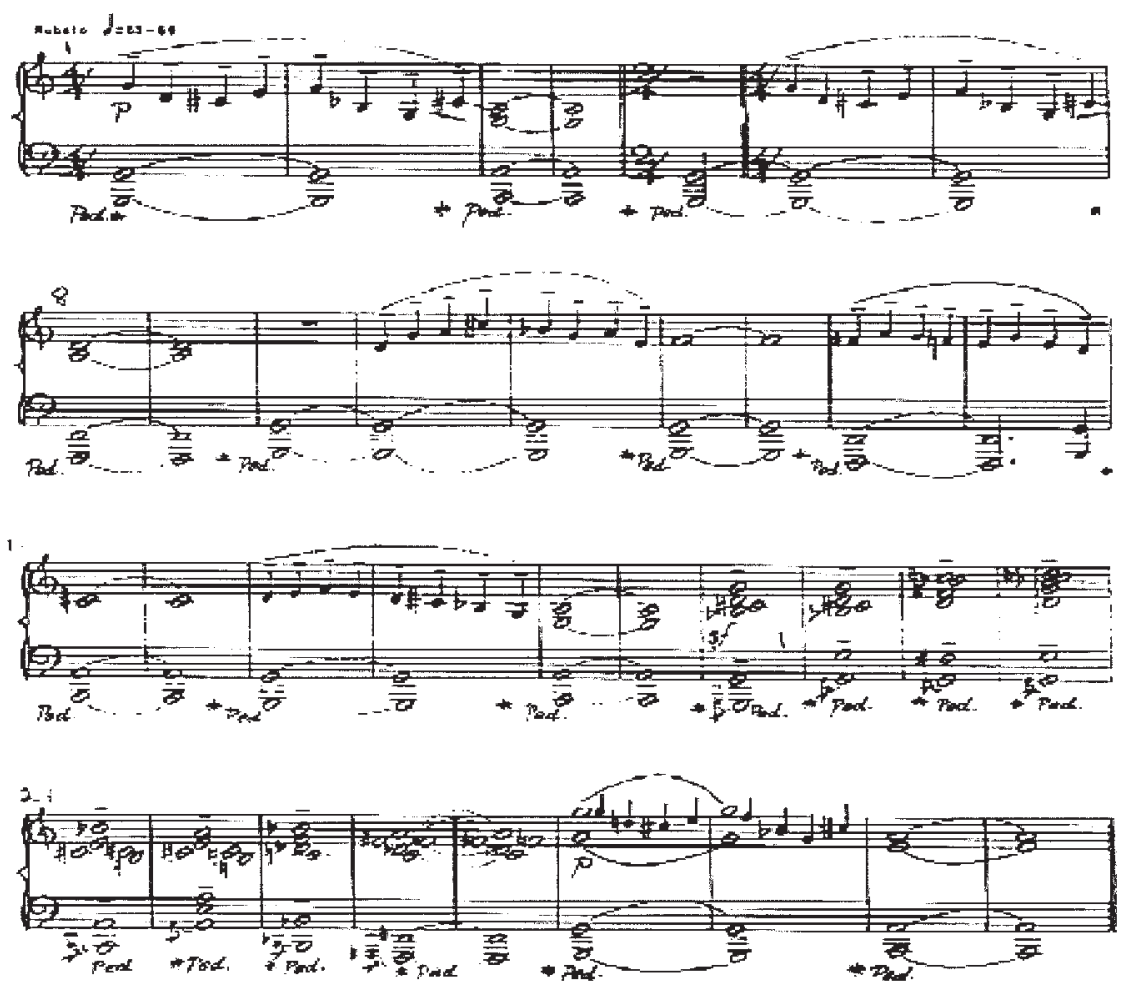

Example 4. Kyriakos Sfetsas, To fōs tēs kaktou (Cactus Light), for solo piano (1980-83), bars $1-35$, with kind permission from the composer

Kyriakos Sfetsas, renowned for his left-wing views, moved to Paris in 1967 following the imposition of the military dictatorship in Greece. He studied composition, analysis, and conducting with Max Deutsch (1892-1982) and sought mentorship and guidance from Xenakis and Nono. He has written music in a variety of styles, but his most effective works are those that fuse the characteristics of Eastern Mediterranean music with jazz and avant-garde techniques. A characteristic example can be found at the beginning of To fōs tès kaktou (Cactus Light, 1980-83). The melodic line in the Introduction is based on the second plagal mode from the byzantine tradition (also known as maqâm Hicaz) on A (A, B flat, C sharp, D, E, F, G, A). The pedal notes accompanying the melody derive from the Greek Orthodox liturgical tradition. Superficially the music may appear to be in D minor. The tonal centre is in fact A (maqâm A Hicaz). This is emphasized by the motive at bar 15, where F sharp and $\mathrm{F}$ lean towards the fifth and seventh degrees of the mode-a characteristic technique of Eastern Mediterranean and Byzantine music (see example 4). The phrase ends on A with a monophonic texture at bars 21-22 and is followed by a series of "Western" clusters. 
Similar examples of the mixing of seemingly incompatible styles can be found in the work of numerous composers, such as George Kouroupos (1942-). The central figure among this group of composers is Theodore Antoniou. As the president of the Greek Composer's Union and as professor of music he played a key role in setting up institutional and intellectual frameworks within which popular traditions and styles could be re-examined from a fresh point of view.

\section{The music of Theodore Antoniou}

Over the past fifty years, Antoniou has established himself on the international scene as a composer, conductor, and professor of composition, and, like Xenakis, he has spent much of his career abroad, notably as professor of composition at the University of Boston. ${ }^{22}$ Nevertheless, Greece and Greek culture have had a profound impact on his work throughout his career. Indeed he proudly put his national identity on display in one of his early opportunities for international recognition. In advance of the 1972 Olympic Games held in Munich, the organizing committee commissioned Antoniou to compose a work for the event. Antoniou composed Nenikèkamen (We won) for mezzo-soprano, baritone, narrator, four-voice choir, and orchestra (1971). The title refers to the legend according to which in $490 \mathrm{BCE}$ the Athenian warrior Philippidēs ran the forty kilometres from Athens to Marathon to announce the victory of the Greeks over the Persians. Upon uttering the word, he collapsed and died of exhaustion. As appropriate as this title may have been for the event, it was certainly out of sync with the tenor of the times. In this regard it is instructive to compare Antoniou's work with another, more well-known work that was also commissioned for the 1972 Games: Exotica for six singing instruments with ten or more non-European instruments (1971-72) by Mauricio Kagel (1931-2008). As the title indicates, the composer asked six professionally trained musicians to perform on non-European instruments. The work is designed to "question the dominance of Western music or 'culture' and to evoke the primeval origins of music-making, when singing was still at one with making sound out of simple, everyday objects" (Universal Edition, n.d.). Kagel's work resonated sympathetically with the reigning ideology of the day that considered unbridled expressions of nationalist pride politically incorrect, particularly in the German Federal Republic.

For Antoniou, cultural identity must be expressed through music and not merely indicated in a title. Examples of national/popular elements can be found throughout his music, including pieces that use neutral titles. For example,

22 He has been engaged by well-known orchestras and has founded and directed various contemporary music ensembles, notably ALEA II and III at Stanford University and Boston University, respectively. His work is published by Bärenreiter, G. Schirmer, and Philippos Nakas, and he is currently professor of composition at Boston University. Antoniou has also received many awards and prizes, including the National Endowment for the Arts Fellowship grants and the Richard Strauss Prize, as well as commissions from the Fromm, Guggenheim, the Koussevitzky Foundations, etc. (ALEA III, n.d.). Finally, over two hundred works have been published by Bärenreiter Verlag, G. Schirmer and Philippos Nakas (Antoniou, 2007). 

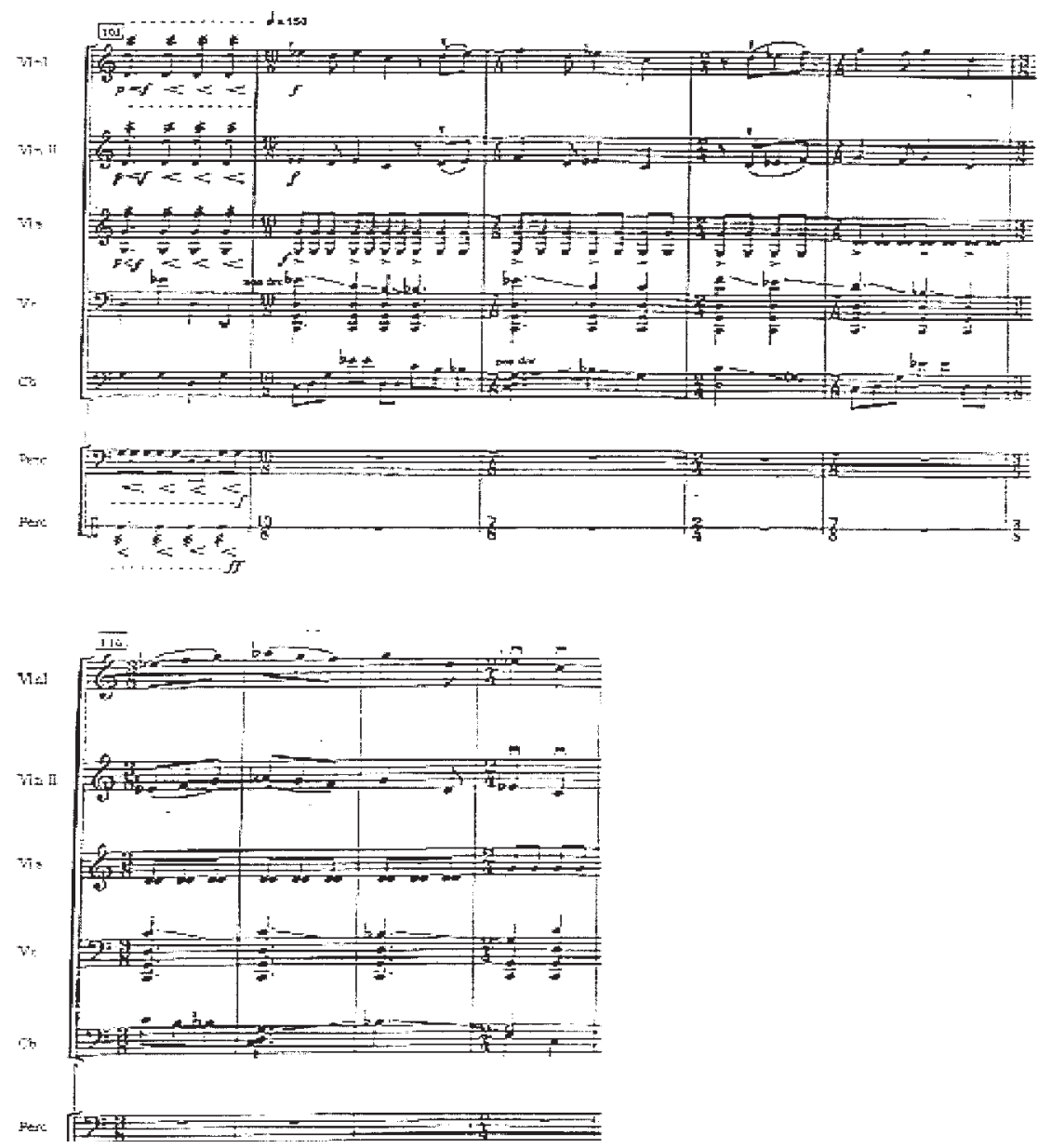

Example 5. Theodore Antoniou, Concerto for Strings, for string orchestra and percussion (1992), bars 105-13, with kind permission from the composer

both the Octet (1986) and the String Concerto (1992) employ melodic material organized in duple and triple rhythmic units that are typical of traditional music in Greece and indeed throughout the Balkan peninsula: for example 5/8 $(3+2), 7 / 8(3+2+2)$, or $9 / 8(3+2+2+2)$ (see bars $106-13$ in example 5$)$.

This intermingling of folk elements is an important aspect of Antoniou's work in all phases of his career. As he worked to master twelve-tone technique in the late 1950 s and early 1960 (see, for example, his Sonatina for Violin and Piano, op. 6, 1958), he was also assimilating the lessons of his first teacher Kalomoirēs (see Antoniou's Deka Ëpirotika Tragoudia [Ten Songs from Ēpirus], 1962). Kalomoirēs encouraged his students to explore Greek traditional music from various regions, appreciate its unique character, and gradually develop personal approaches to the integration of aspects of this music into their compositions. However, Antoniou was not constrained by the narrow stylistic 


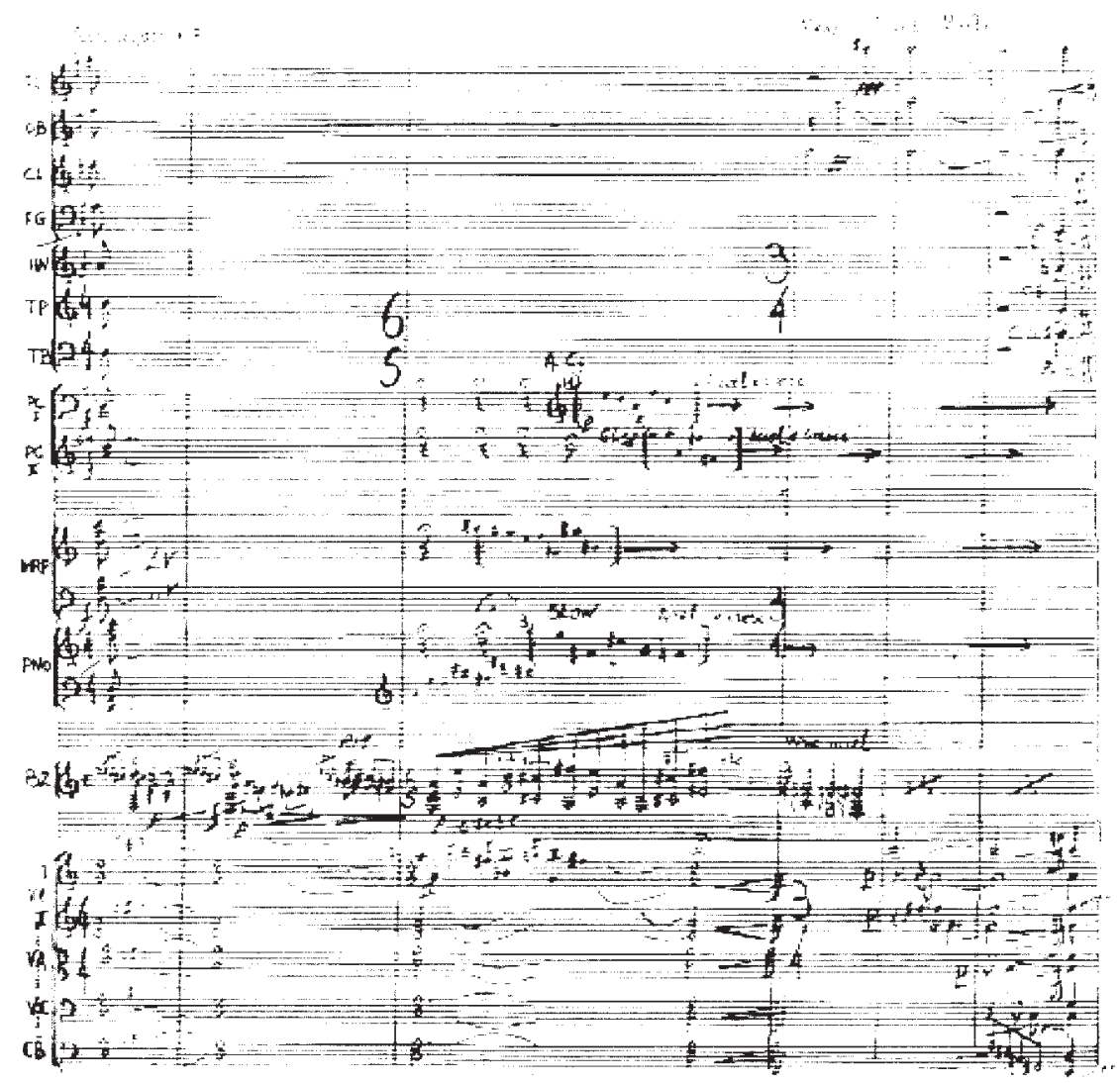

Example 6. Theodore Antoniou, Concerto for Tambura (Bouzouki) and Orchestra, bars $1-6$, with kind permission from the composer

conventions of the Greek National School based largely on Kalomoirēs's reception of Wagner. His quest for his own voice led him to explore new ways and means to integrate the elements of Greek traditional music into contemporary composition. A characteristic example in Antoniou's later work is the Concerto for Tambura (Bouzouki) and Orchestra (1988). ${ }^{23}$ The composition presents a compelling example of cultural blending and stylistic métissage, which can be seen on the very first page of the work. Antoniou demands new and usual techniques from the soloist, turning the sound colour of the bouzouki into a thematically charged musical gesture (see bar 3 in example 6).

By the end of the twentieth century, Greek composers were creatively exploring all aspects of their musical traditions. Fascinated by the use of pentatonic scales in the Greek moirologia, Antoniou used stylistic aspects of these

23 The premiere of the work took place in Hēraklion, Crete, on 27 August 1988, during the "Musical August" Festival, with Chrēstos Cōnstantinou as the soloist and the orchestra of Boston ALEA III, conducted by the composer. 


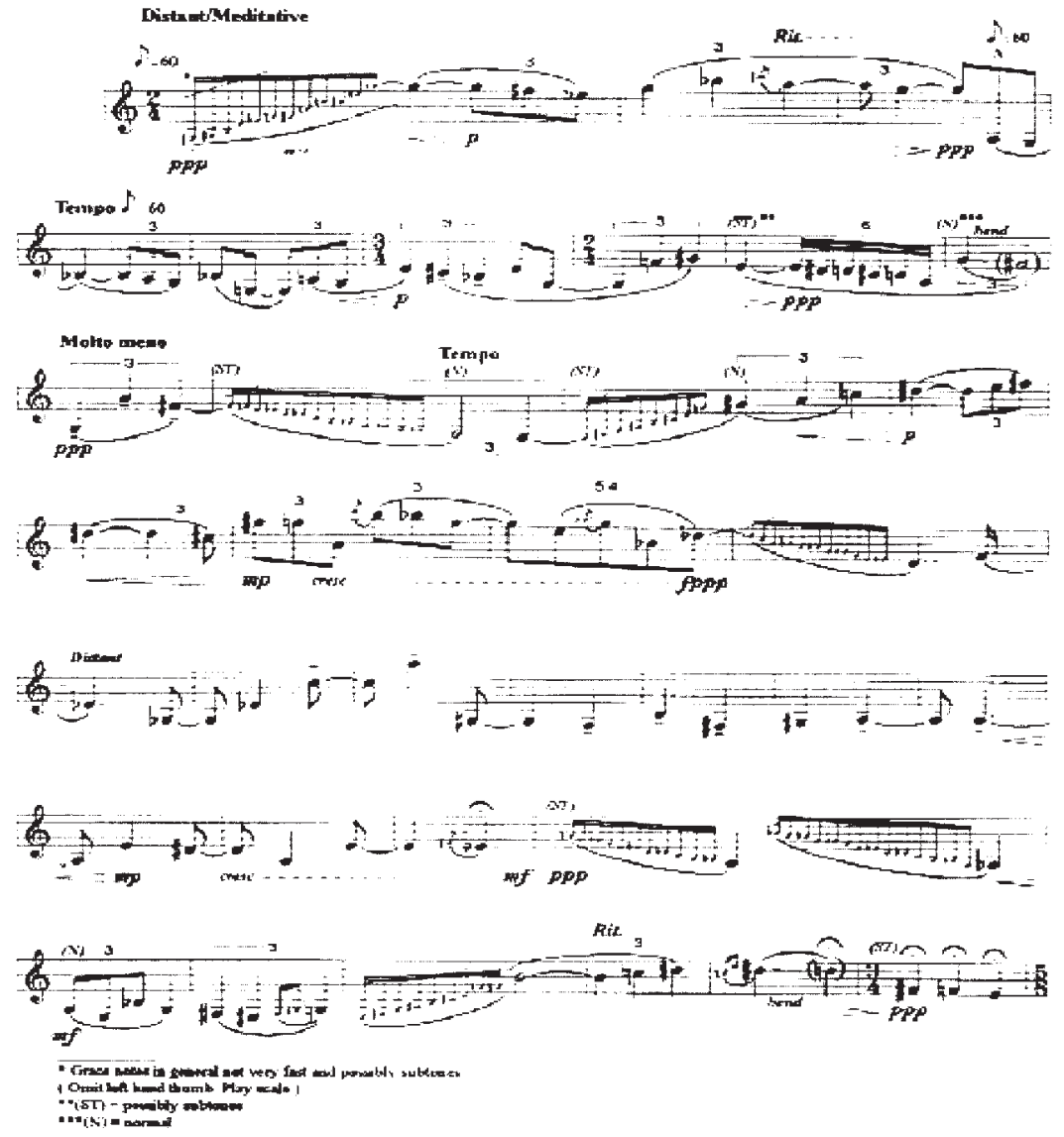

Example 7. Theodore Antoniou, Lament for Manos, for solo clarinet (1995), bars 1-34, with kind permission from the composer

traditional lament songs as the basis for a number of instrumental works. $\mathrm{La}$ ment for Michelle for solo flute (1988) and Lament for Manos for solo clarinet (1995) are characterized by the exploration of timbres and techniques associated with the melodic world of folk music practice on the traditional type of these instruments. The latter work was written for Manos Hatzidakis (1925-94), one of the most influential Greek songwriters and composers of the twentieth century, an important promoter of the rebetika style and a close friend of Antoniou. In this work, the nuances of the traditional laments are recalled by typical short slips (indicated on the score by the word bend, see bar 9 in example 7). The slow appoggiaturas (as noted with the composer's directions on the score) reconstitute on the clarinet the characteristic sobs of these dirges. The subtones, the short slips, the slow appoggiaturas, etc., are associated with the traditional music practice from Greece and are so successfully woven into the extended techniques of Western contemporary music that it is difficult to separate the two practices. 
Another striking example of Antoniou's ability to weave different styles into a compelling whole and of his engagement with traditional music can be seen in his Laments, for narrator, soprano, solo violin, chorus, and orchestra (2004), one of the most dramatic and complex compositions he has written. This work was commissioned by the University of Boston following the untimely death of Antoniou's friend and colleague John Daverio, the musicologist, violinist, and polyglot. Antoniou composed a work that is not only an expression of bereavement for the loss of his good friend, but also a vivid portrait of Daverio's versatile mind. Antoniou employed the folk dirges of countries and languages that Daverio knew, and he used the solo violin (Daverio's instrument) to hold this stylistic diversity together. Antoniou's work underscores the global character of grief and shows that the Greek source material is universally significant. At the same time, it also demonstrates that identity is normally a métissage made up of many and various components.

\section{CONCLUding ReMARKS}

Identity is and has always been both individual and collective. During the nineteenth century, the emerging nation-states reinforced their legitimacy by forging and promoting national identities with attendant political, cultural, and moral claims (Ignatieff 1993, xii). In this process the newly invented concepts of art and folk music were conscripted to serve national ends (Bohlman 2012, 34-6). Following the Second World War and the Holocaust, nationalism and collective identity have become problematic topics to deal with. Furthermore the triumph of the mass-consumption societies in the West has led to the promotion of identity as primarily an individual phenomenon: a construction of personally enacted values. The result can be a completely unstructured or de-structured society modelled on Los Angeles: "a desert of detail without shape, the paradise (or hell) of those who 'did their own thing"' (Hobsbawm 1994, 516). Seen from this perspective, communal or collective values are often judged to be old-fashioned, superannuated concepts that tend to transform culture into static, formulaic, politically charged clichés. The past decades have witnessed a resurgent discussion of collective identity, including a re-evaluation of the role of the nation-state. Michael Ignatieff (1993, xxii-xxiii) noted that no other institution has the capacity to provide security and civility to its citizens, a point that resonates in recent writing about music. Ian Biddle and Vanessa Knights $(2007,11)$ have argued that between the extremes of the local and the global we need to recapture the middle ground (that imagined or real place that enables the discursive existence of regional or national identities). While recognizing that unbridled nationalism can beget intolerance, bigotry, xenophobia, and genocide, we should not forget that communities both small and large constitute irreplaceable vehicles for the transmission of culture, as well as indispensable contexts for understanding and interpreting it. Language itself is a consequence of community.

Coming back to Greece, how does the work of twentieth-century composers from Skalkōttas to Antoniou differ from that of, say, Bartók and Kodály, 
who undertook to establish a national music culture based on the music of the Hungarian peasantry? First, the Byzantine tradition and rural folk music did not have to be rediscovered in the way that Bartók and Kodály "unearthed" Hungarian folk music. Byzantine liturgical music, as well as rural folk music, was well known and easily accessible. These sources continue to inspire and stimulate new music to this day (for more on the strong relationship between the Byzantine legacy and the popular music of Greece, see Baud-Bovy 1983). Second, in the music of Kodály and Bartók (during the early phases of his career), there is a clear sense that they were using elements of folk music (from Hungary) to establish a "high" art style that would be recognizable as specifically Hungarian (Kodály 1964, 70-71). As mentioned above, the stark division between high- and low-brow styles that was and continues to be so characteristic of Western European music cultures is not nearly as strongly felt in the music of Greece. In Bartók's late work, we do find pieces such as Contrasts for violin, clarinet, and piano (written for Joseph Szigeti, Benny Goodman, and himself) that attempt to override this stylistic division, but this work is an exception that confirms the rule. In Greece the situation is different. Rather than being relegated to an imaginary museum, the popular and folk traditions of Greece continue to evolve and irrigate the musical culture of Greece as a whole.

The division between high- and low-brow styles is a legacy of Romantic aesthetics that is now fading. Consequently, the music of Greece is not only different, it can be seen as a model to emulate, and this would not be new. For more than a thousand years, the music cultures of the West have been regularly rejuvenated and reinvented by going back to Greece and its cultural legacy. After all, Greece has always been the taproot of the Western world and will continue to exercise this function even as Western culture transforms itself into something new.

\section{ACKNOWLedgements}

We are indebted to Kaiti (Katy) Romanou, professor of musicology, University of Athens, for her suggestions and advice on issues related to Greek music.

\section{REFERENCES}

Adorno, Theodore. (1949) 2006. Philosophy of New Music. Translated and edited by Robert Hullot-Kentor. Minneapolis: University of Minnesota Press.

ALEA III. n.d. "About Theodore Antoniou." http://www.aleaiii.com/theodore -antoniou/.

Antoniou, Theodore. 2007. Works Catalogue. Athens: Philippos Nakas.

Barulich, Frances M., and Paul E. Schlotthauer. 2005. "Chronology: Music, Other Arts and Philosophy, History." Richard Taruskin. The Oxford History of Western Music. New York: Oxford University Press, 6:1-65.

Baud-Bovy, Samuel. 1983. Essai sur la Chanson Populaire Grecque. Nauplion: Fondation ethno-graphique du Péloponnèse.

Beal, Amy C. 2006. New Music, New Allies: American Experimental Music in West Germany from the Zero Hour to Reunification. Berkeley: University of California Press. 
Biddle, Ian, and Vanessa Knights, eds. 2007. "Introduction: National Popular Musics-Betwixt and between the Local and the Global." In Music, $\mathrm{Na}$ tional Identity and the Politics of Location: Between the Global and the Local. Edited by Biddle and Knights, 1-18. Aldershot, UK: Ashgate.

Bohlman, Philip V. 2012. "Music and Culture: Historiographies of Disjuncture, Ethnographies of Displacement." In The Cultural Study of Music: A Critical Introduction. 2nd ed. Edited by Martin Clayton, Trevor Herbert, and Richard Middleton, 28-39. New York: Routledge.

Boulez, Pierre. 1970. “Sprengt die Opernhäuser in die Luft!” In ... wir danken Ihnen für dieses Gespräch: 24 Spiegel Gespräche, edited by Walter Busse, 285-94. Munich: Deutsche Taschenbuch Verlag.

Burkholder, Peter J., Donald J. Grout, and Claude V. Palisca. 2010. A History of Western Music. 8th ed. New York: W. W. Norton.

Central Intelligence Agency (CIA). 1950. "Current Situation in Greece." http://www.foia.cia.gov/sites/default/files/document_conversions/89801/ DOC_0000258841.pdf.

Curry, Robert. 2011. "Music East of the Rhine." In The Cambridge Companion to Medieval Music, edited by Mark Everist, 171-82. Cambridge, UK: Cambridge University Press.

Dahlhaus, Carl. 1989. Between Romanticism and Modernism: Four Studies in the Music of the Late Nineteenth Century. Translated by Mary Whittall. Berkeley: University of California Press.

Duchesneau, Louise, and Wolfgang Marx, eds. 2011. György Ligeti: Of Foreign Lands and Strange Sounds. Woodbridge, ON: Boydell.

Ferguson, Niall. 2012. Civilization: The West and the Rest. London: Penguin Books.

Gelbart, Matthew. 2007. The Invention of "Folk Music" and "Art Music": Emerging Categories from Ossian to Wagner. Cambridge, UK: Cambridge University Press.

Handschin, Jacques. 1990. Musik Geschichte im Überblick. 4th ed. Wilhelmshaven: Florian Noetzel Verlag.

Hobsbawm, Eric. 1994. Age of Extremes: The Short Twentieth Century 1914-1991. London: Abacus.

- 2012. "Introduction: Inventing Traditions." In The Invention of Tradition, edited by Eric Hobsbawm and Terrence Ranger, 1-14. Cambridge, UK: Cambridge University Press and Canto edition.

Hoppin, Richard H. 1978. Medieval Music. New York: W. W. Norton.

Ignatieff, Michael. 2006. Blood and Belonging: Journeys into the New Nationalism. London: Penguin.

Johnson, David Martel. 2003. How History Made the Mind: The Cultural Origins of Objective Thinking. Chicago: Open Court.

Kaldellis, Anthony. 2007. Hellenism in Byzantium: The Transformations of Greek Identity and the Reception of the Classical Tradition. Cambridge, UK: Cambridge University Press.

Kerman, Joseph. 1985. Musicology. London: Fontana/Collins. 
Kodály, Zoltán. (1925) 1964. “Thirteen Young Hungarian Composers.” In The Selected Writings of Zoltán Kodály, edited by Ferenc Bónis, translated by Lili Halápy and Fred Macnicol, 70-74. Budapest: Corvina.

Kramer, Lawrence. 1996. Classical Music and Postmodern Knowledge. Berkeley: University of California Press.

Kundera, Milan. 2005. Testaments Betrayed: An Essay in Nine Parts. Translated by Linda Asher. New York: Harper Collins.

Leotsakos, George. 2001. "The Athens Conservatory and the National School."

Edited by Kostas Moschos. Edited and translated by Natalia Tsakmakidou. Greek Music Information Center. http://www.musicportal.gr/ greek_modern_music_athens_conservatoire/?lang=en.

Mazower, Mark. 2002. The Balkans: From the End of Byzantium to the Present Day. London: Phoenix.

McEwan, Cheryl. 2009. Postcolonialism and Development. London: Routledge. Pentland, Barbara. 1950. "Canadian Music, 1950." Northern Review 3 (3): 43-46. Poulakis, Nick. 2009. "Chrēstou, Adamēs, Koukos: Greek Avant-garde Music during the Second Half of the 2oth Century." In Serbian and Greek Art Music: A Patch of Western Music History, edited by Katy (Katie) Romanou, 187-203. Bristol, UK: Intellect Books.

Psychopaidēs, Kosmas. 1997. Politics within Meanings. Athens: Nēsos.

Romanou, Katy (Kaiti). 200o. Istoria tēs Ellinikēs Entehnēs Mousikēs [History of Greek Art Music]. Athens: Koultoura.

_.2006. “Stochastic Jeux." Poliphonia 9:207-18.

2009. "The Ionian Islands" and "Nikos Skalkōttas." In Romanou 2009, 99-124 and 163-86 respectively.

Sallis, Friedemann. 2000. "Le paradoxe postmoderne et l'œuvre tardive de Luigi Nono." Circuit musiques contemporaines 11 (1): 69-84.

- 2003. "Deconstructing the Local: The Aesthetic Space and Geographic Place of Oscar Morawetz's String Quartet No. 5 'A Tribute to Wolfgang Amadeus Mozart' (1991)." Canadian University Music Review / Revue de musique des universités canadiennes 24 (1): 7-29.

- 2011a. "Introduction." In Centre and Periphery, Roots and Exile: Interpreting the Music of István Anhalt, György Kurtág and Sándor Veress, edited by Friedemann Sallis, Robin Elliott, and Kenneth DeLong, 1-25. Waterloo, ON: Wilfrid Laurier University Press.

-2011b. "'We play with music and the music plays with us': Sándor Veress and His Student György Ligeti." In Duchesneau and Marx 2011, 1-16.

Samson, Jim. 2010. "Little Stories for the Balkans." In Music and Displacement: Diaspora, Mobilities, and Dislocations in Europe and Beyond, edited by Erik Levi and Florian Scheding, 181-95. In Europea: Ethnomusicologies and Modernities, no. 10. Edited by Philip V. Bohlman and Martin Stokes. Lanham, MD: Scarecrow.

Schoenberg, Arnold. 1975. Style and Idea: Selected Writings. Edited by Leonard Stein. Translated by Leo Black. Berkeley: University of California Press.

Steinitz, Richard. 2011. "À qui un homage? Genesis of the Piano Concerto and the Horn Trio." In Duchesneau and Marx 2011, 169-212. 
Strohm, Reinhard. 1992. "Centre and Periphery: Mainstream and Provincial Music." In Companion to Medieval and Renaissance Music, edited by Tess Knighton and David Fallows, 55-59. Berkeley: University of California Press.

Taruskin, Richard. 2005. The Oxford History of Western Music. New York: Oxford University Press.

Taruskin, Richard, and Piero Weiss, eds. 2008. Music in the Western World: A History in Documents. Belmont: Schirmer.

Terzakis, Dimitri. n.d. "Biography.” http://dimitriterzakis.com/vita_en.html.

Universal Edition. n.d. "Mauricio Kagel." http://www.universaledition.com /mauricio-kagel/composers-and-works/composer/349/work/2397/ work_introduction.

Vrondos, Haris, ed. 2009. Nikos Skalkōttas: A Greek European. Athens: Benaki Museum.

Zervos, Yōrgos. 2001. Nikos Skalkōttas and the European Tradition of the Early 2oth Century. Athens: Papagrēgoriou-Nakas.

\begin{abstract}
This study addresses aspects of local identity in the music of Theodore Antoniou and other Greek contemporary composers. It highlights misapprehensions and obsolete conceptions of historiography and aesthetics embedded in the use of terms such as centre and periphery or high-and low-brow styles of music, respectively. An overview of the history of art music in Greece is attempted, for a better understanding of these issues in that context. The parallel reference to significant Western contemporary composers such as György Ligeti, Luigi Nono, and Mauricio Kagel supports the primary argument of the essay, which seeks fair treatment for all places that find themselves peripheral to a given centre. The case of Greece-one of the cradles of Western culture-is a unique example of a problematic approach typical of Western historiographies with regard "centres" and "peripheries" that needs to be corrected.
\end{abstract}

\title{
RÉSUMÉ
}

Cette étude examine divers aspects de l'identité locale dans la musique de Theodore Antoniou et d'autres compositeurs grecs contemporains. On y met en lumière les malentendus et les concepts historiographiques et esthétiques désuets implicites dans l'utilisation de termes tels que «centre» et "périphérie», ainsi que styles musicaux «élevés» et «bas». On cherche, à travers un survol de l'histoire de la musique savante grecque, à atteindre une meilleure compréhension de ces questions dans ce contexte. La comparaison avec les compositeurs contemporains d'importance tels que György Ligeti, Luigi Nono et Mauricio Kagel soutient la nécessité d’un regard équitable sur toutes les manifestations se trouvant à être à la périphérie d'un centre donné. Le cas de la Grèce - le berceau de la civilisation occidentale - est un exemple important de l'approche problématique de l'historiographie occidentale au regard des concepts de «centre» et de «périphérie», et qui devrait être corrigé. 